DOI:10.17951/h.2020.54.4.83-100

\begin{tabular}{lc}
\hline \multicolumn{1}{c}{ A N N A L E S } \\
UNIVERSITATIS MARIAE CURIE-SKŁODOWSKA \\
LUBLIN - POLONIA \\
SOL. LIV, 4 \\
\hline
\end{tabular}

\author{
ANNA NOWACKA \\ prorektor@mazowiecka.edu.pl \\ Mazowiecka Uczelnia Publiczna w Płocku \\ pl. Dąbrowskiego 2, 09-402 Płock, Polska \\ ORCID ID: https://orcid.org/0000-0001-9300-3646
}

\title{
Stosunek do edukacji finansowej w obszarze zarzadzania finansami osobistymi a poziom transakcyjnego wykluczenia finansowego osób bezrobotnych $w$ świetle badań własnych*
}

\footnotetext{
The Attitude to Financial Education in the Area of Personal Finance Management and the Level of Transactional Financial Exclusion of the Unemployed in the Light of Own Research
}

Keywords: financial education; personal finance management; transactional financial exclusion; unemployed

Słowa kluczowe: edukacja finansowa; zarządzanie finansami osobistymi; transakcyjne wykluczenie finansowe; osoby bezrobotne

JEL: A29; D14; G50

Propozycja cytowania: Nowacka, A. (2020). Stosunek do edukacji finansowej w obszarze zarządzania finansami osobistymi a poziom transakcyjnego wykluczenia finansowego osób bezrobotnych w świetle badań własnych. Annales Universitatis Mariae Curie-Skłodowska, sectio H-Oeconomia, Vol. 54, No. 4.

\begin{abstract}
Theoretical background: The attitude to financial education in the area of personal finance management can be determined by many factors, i.a. the socio-demographic ones and the degree of transactional financial exclusion. The phenomenon of is related to the degree of banking.
\end{abstract}

* Artykuł został opracowany w ramach grantu naukowo-badawczego zrealizowanego w latach 2018-2019, sfinansowanego ze środków Gminy - Miasta Płock (nr umowy 20/WEK-I/Z/607/2019). 
Purpose of the article: Examination of the relationship between the attitude of the unemployed to the financial education in the area of personal finance management and different levels of transactional financial exclusion. The study focuses on one of the segments of financial exclusion, i.e. banking financial exclusion in the area of access to payment transactions, measured by the level of banking.

Research methods: The analysis of the attitude to financial education in the area of personal finance management as well as the levels of transactional financial exclusion was based on the own research and review of the literature on the subject. The data obtained as a result of the study with the use of a questionnaire on the 350 unemployed people registered at the Municipal Employment Office in Płock were used to verify three research hypotheses.

Main findings: The obtained results of the analysis indicate a relationship between the attitude to financial education in the area of personal finance management and selected socio-demographic characteristics of the unemployed (age, education and the period of registration with the employment office) and three levels of banking. However, no statistically significant dependence was found between the subjective assessment of financial skills in the area of personal finance management and the degree of transactional financial exclusion. Taking into account the results of the analysis, it seems essential to undertake educational initiatives among the unemployed aimed at limiting the degree of transactional financial exclusion.

\begin{abstract}
Abstrakt
Uzasadnienie teoretyczne: Stosunek do edukacji finansowej w obszarze zarządzania finansami osobistymi może być determinowany wieloma czynnikami, m.in. społeczno-demograficznymi oraz stopniem transakcyjnego wykluczenia finansowego. Zjawisko to związane jest ze stopniem ubankowienia.

Cel artykułu: Określenie stosunku osób bezrobotnych do edukacji finansowej w obszarze zarządzania finansami osobistymi w zależności od poziomu transakcyjnego wykluczenia finansowego. W opracowaniu skoncentrowano się na jednym z segmentów wykluczenia finansowego, tzn. bankowym wykluczeniu finansowym w zakresie dostępu do transakcji płatniczych, mierzonym poziomem ubankowienia.

Metody badawcze: Analiza stosunku do edukacji finansowej w obszarze zarządzania finansami osobistymi oraz do poziomów transakcyjnego wykluczenia finansowego została oparta na badaniach własnych i przeglądzie literatury przedmiotu. Dane uzyskane w wyniku przeprowadzonego badania z wykorzystaniem kwestionariusza ankiety na próbie 350 osób bezrobotnych zarejestrowanych w Miejskim Urzędzie Pracy w Płocku wykorzystano do weryfikacji trzech hipotez badawczych.

Główne wnioski: Uzyskane wyniki badania wskazują na związek stosunku do edukacji finansowej w obszarze zarządzania finansami osobistymi z wybranymi cechami społeczno-demograficznymi osób bezrobotnych (takimi jak wiek, wykształcenie i okres zarejestrowania w urzędzie pracy) oraz z trzema poziomami ubankowienia. Nie stwierdzono natomiast istotnej statystycznie zależności między oceną umiejętności finansowych w obszarze zarządzania finansami osobistymi a stopniem transakcyjnego wykluczenia finansowego. Biorąc pod uwagę wyniki przeprowadzonej analizy, zasadne wydaje się podejmowanie inicjatyw edukacyjnych wśród osób bezrobotnych, mających na celu ograniczanie stopnia transakcyjnego wykluczenia finansowego.
\end{abstract}

\title{
Wprowadzenie
}

Poziom wiedzy ekonomicznej stopniowo poprawia się dzięki inicjatywom podejmowanym przez instytucje finansowe. Dużą aktywnością na tym polu wykazują się banki, a w szczególności Narodowy Bank Polski, który prowadzi różnorodne działania edukacyjne mające na celu podniesienie świadomości finansowej.

Mimo łatwego dostępu do informacji poziom znajomości mechanizmów finansowych w społeczeństwie polskim nie jest wciąż zadowalający. Wynika to również 
z faktu, że współczesny rynek finansowy ulega dynamicznym zmianom, a oferowane produkty i usługi są mocno zróżnicowane i nie zawsze w sposób przejrzysty oferowane. Dokonywanie właściwych wyborów w zakresie alokacji kapitału czy źródeł finansowania na poziomie gospodarstwa domowego wymaga poznania specyfiki instrumentów finansowych oraz uwarunkowań rynku finansowego. Dlatego tak ważną rolę w procesie zarządzania finansami osobistymi odgrywa edukacja finansowa, w której nacisk jest położony na uświadamianie obywatelom zagrożeń i możliwości związanych z produktami i usługami finansowymi.

Deficyt kompetencji w tym zakresie przyczynia się do wykluczenia finansowego, ponieważ stanowi barierę $\mathrm{w}$ korzystaniu w pełnym zakresie $\mathrm{z}$ usług rynku finansowego. Grupą szczególnie narażoną na wykluczenie finansowe są osoby bezrobotne, które na co dzień żyją z oszczędności, o ile takie posiadają, a także z zasiłku czy zapomogi lub są na utrzymaniu rodziny albo czerpią dochody z pracy nierejestrowanej. Brak dochodów lub niemożność ich udokumentowania to poważna przeszkoda w korzystaniu z usług finansowych: kredytów, pożyczek, posiadania konta bankowego, dokonywania operacji finansowych.

\section{Pojęcie edukacji finansowej}

Edukacja finansowa jest częścią edukacji i zarazem stanowi element składowy edukacji ekonomicznej. Organizacja Współpracy Gospodarczej i Rozwoju (OECD) zaproponowała w 2005 roku następującą definicję edukacji finansowej:

[...] edukacja finansowa to proces, w którym zarówno konsumenci, jak i inwestorzy finansowi poprawiają swoje rozumienie produktów finansowych, koncepcji i zagrożeń oraz poprzez informacje, instrukcje i/lub obiektywne porady rozwijają umiejętności i pewność siebie, aby lepiej poznać zagrożenia finansowe i możliwości, dokonać świadomych wyborów, wiedzieć, gdzie szukać pomocy, a także podjąć inne skuteczne działania w celu poprawy ich dobrobytu finansowego. (OECD, 2016)

Orzeszko (2014, s. 275) zwraca uwagę, że edukacja finansowa obejmuje wiedzę finansową, umiejętności finansowe, świadomość finansową, nastawienie do produktów finansowych oraz reakcje na rynku finansowym (schemat 1).

EDUKACJA FINANSOWA

\begin{tabular}{|c|c|c|c|c|}
\hline $\begin{array}{c}\text { Wiedza } \\
\text { finansowa }\end{array}$ & $\begin{array}{c}\text { Umiejętności } \\
\text { finansowe }\end{array}$ & $\begin{array}{c}\text { Świadomość } \\
\text { finansowa }\end{array}$ & $\begin{array}{c}\text { Nastawienie do } \\
\text { produktów finansowych }\end{array}$ & $\begin{array}{c}\text { Reakcje } \\
\text { finansowe }\end{array}$ \\
\hline
\end{tabular}

ZNAJOMOŚĆ MECHANIZMÓW FINANSOWYCH (FINANCIAL LITERACY)

EFEKTYWNE ZARZĄDZANIE FINANSAMI OSOBISTYMI

Schemat 1. Edukacja finansowa

Źródło: opracowanie własne na podstawie (Orzeszko, 2014, s. 275). 
Można zatem stwierdzić, że celem edukacji finansowej jest poznanie mechanizmów finansowych, które umożliwią bardziej efektywne zarządzanie finansami osobistymi (Lusardi \& Mitchel, 2014). Atkinson i Messy (2012, s. 5) podkreślają, że znajomość mechanizmów finansowych (financial literacy) to połączenie świadomości, wiedzy, umiejętności, postawy i zachowania, niezbędnych do podejmowania właściwych decyzji finansowych, a ostatecznie do osiągnięcia indywidualnego dobrobytu finansowego. Wiedza finansowa to umiejętność rozumienia finansów. Pojęcie financial literacy odnosi się do zestawu umiejętności i wiedzy, który umożliwia jednostce podejmowanie przemyślanych i efektywnych decyzji poprzez rozumienie finansów (Musiał, 2016). Z kolei zdaniem Świeckiej (2018, s. 6) „,edukacja finansowa" to pojęcie wielowymiarowe, które należy traktować jako proces, wartość, zespół działań, obszar wielozadaniowy oraz kapitał (tabela 1).

Tabela 1. Definicje edukacji finansowej

\begin{tabular}{|l|l|}
\hline \multicolumn{1}{|c|}{$\begin{array}{c}\text { Edukacja } \\
\text { finansowa jako }\end{array}$} & \multicolumn{1}{c|}{ Opis } \\
\hline Kapitał & $\begin{array}{l}\text { Edukacja finansowa jest kapitałem niefizycznym; dobrem, które powinno być zwiększane } \\
\text { w celu eliminacji ubóstwa, biedy i nędzy }\end{array}$ \\
\hline Wartość & $\begin{array}{l}\text { Jeśli uznać, że edukacja finansowa jest kapitałem, w który warto inwestować, a kapitał to } \\
\text { „samopomnażająca się" wartość, to można przyjąć, że edukacja finansowa jest społeczną } \\
\text { wartością, która wyposaża w wiedzę i umiejętności przygotowujące do funkcjonowania } \\
\text { w sferze finansów }\end{array}$ \\
\hline $\begin{array}{l}\text { Obszar } \\
\text { wielozadaniowy }\end{array}$ & $\begin{array}{l}\text { Edukacja finansowa jest obszarem wielozadaniowym, wymagającym ciągłego pogłębiania } \\
\text { i aktualizowania }\end{array}$ \\
\hline Zespół działań & $\begin{array}{l}\text { Edukacja finansowa jest zespołem działań mających na celu zwiększenie wiedzy finansowej, } \\
\text { rozwijanie umiejętności i wykształcenie pozytywnych nawyków służących do racjonalnego } \\
\text { i efektywnego gospodarowania finansami, a także umiejętnego wykorzystania produktów } \\
\text { i narzędzi finansowych }\end{array}$ \\
\hline Proces & $\begin{array}{l}\text { Edukacja finansowa jest procesem zwiększania kompetencji finansowych, rozpoczynającym } \\
\text { się od pogłębiania wiedzy i nabywania umiejętności, a prowadzącym do zmiany postaw } \\
\text { i zachowan. Proces ten może się rozpocząć na każdym etapie rozwoju i trwać przez całe życie }\end{array}$ \\
\hline Ochrona & $\begin{array}{l}\text { Edukacja finansowa jest zespołem narzędzi służących do ochrony przed niewłaściwymi } \\
\text { decyzjami, które mogą skutkować negatywnymi konsekwencjami finansowymi }\end{array}$ \\
\hline
\end{tabular}

Źródło: (Świecka, 2018, s. 6).

Zaprezentowane w tabeli 1 definicje edukacji finansowej uwypuklają jej rolę w procesie zdobywania wiedzy finansowej, a następnie umiejętności, które powinny służyć podejmowaniu racjonalnych decyzji finansowych. Należy pamiętać, że proces ten może rozpocząć się na każdym etapie życia i trwać przez całe życie w myśl koncepcji Life Long Learning ${ }^{1}$.

1 Idea edukacji przez całe życie pojawiła się już na początku XX wieku. Jednakże jako uniwersalna i humanistyczna koncepcja została ukształtowana w latach 70. przy udziale UNESCO. Zakładała, że „każdy człowiek ma prawo i powinien uczyć się przez całe swoje życie” (raporty "Wprowadzenie do koncepcji uczenia się przez całe życie” Lengranda oraz „Uczyć się, aby być. Świat edukacji dziś i jutro” Faure'a). 


\section{Znaczenie edukacji finansowej w obszarze zarządzania finansami osobistymi}

Prezentowane przez różnych autorów definicje finansów osobistych są często odnoszone do pojęcia finansów gospodarstw domowych (Campbell, 2006; Garman \& Forgue, 2008; Korenik \& Korenik, 2004; Waliszewski, 2010). Świecka (2014) również utożsamia pojęcie finansów osobistych z pojęciem finansów gospodarstw domowych, zwracając uwagę, że ,finanse osobiste sensu largo to subdyscyplina finansów związana z gospodarowaniem (zarządzaniem) środkami finansowymi przez członków gospodarstw domowych".

„Finanse osobiste” to pojęcie obejmujące ogół procesów i zjawisk związanych z pozyskiwaniem, gromadzeniem i wydatkowaniem zasobów pieniężnych przez osoby fizyczne nieprowadzące działalności gospodarczej. Proces ten polega na podejmowaniu działań pozwalających na utrzymanie bieżącej i długoterminowej płynności oraz na efektywną realizację celów (Barembruch, 2012). W definicji tej został uwypuklony aspekt zarządzania finansami osobistymi, na który zwracają uwagę również inni autorzy (zob. Garman \& Forgue, 2008; Musiał, 2016; Waliszewski, 2010), wskazując, że jest to proces ciągłego gospodarowania pieniędzmi, składający się z czynności związanych z przygotowaniem i realizacją operacji pieniężnych. Do czynności tych można zaliczyć: uzyskiwanie dochodów, wydawanie, oszczędzanie, inwestowanie, pożyczanie, zarządzanie ryzykiem, planowanie emerytalne i podatkowe oraz transfer majątku (Musiał, 2016).

W literaturze przedmiotu wskazywany jest związek między edukacją finansową a korzystaniem z usług finansowych (Iwanicz-Drozdowska, 2009). Osoby nieposiadające podstawowej wiedzy z zakresu finansów rzadziej i mniej świadomie korzystają z usług finansowych. Edukacja finansowa jest niezwykle ważnym narzędziem, mającym zasadnicze znaczenie w procesie zarządzania finansami osobistymi. Może pomóc klientom zarówno rozwinąć umiejętności porównywania i wybierania produktów finansowych odpowiadających ich potrzebom, jak i umożliwić korzystanie z praw ochrony konsumenckiej (Cohen \& Nelson, 2011, s. 4).

Frączek (2014) zauważa, że odpowiedni poziom wiedzy finansowej przyczynia się do lepszego dysponowania własnymi środkami finansowymi zgodnie z potrzebami oraz ułatwia dokonywanie wyborów z szerokiej gamy usług finansowych. Dlatego też przez wielu autorów podnoszona jest kwestia wpływu edukacji finansowej na proces zarządzania środkami finansowymi w gospodarstwie domowym. Demirguc-Kunt, Klapper i Singer (2017) podkreślają rolę podnoszenia świadomości finansowej w zakresie gromadzenia oszczędności w instytucjach finansowych i ograniczania kultu gotówki oraz w procesie planowania zabezpieczenia emerytalnego (na ten temat zob. także: Lusardi \& Mitchell, 2011a, 2011b; Rooij, Lusardi, \& Alessie, 2011).

Ponadto wskazuje się na korelację między wiedzą finansową a umiejętnościami codziennego zarządzania finansami (Hilgert, Hogarth, \& Beverly, 2003). Zależność ta stała się przedmiotem badania, którego wyniki zaprezentowała w swoim opracowaniu Kłopocka (2018). 


\section{Transakcyjne wykluczenie finansowe}

Pod względem segmentów produktów finansowych Bank Światowy wyróżnia następujące obszary wykluczenia finansowego: bankowość transakcyjna, oszczędności, kredyty, ubezpieczenia (European Commission, 2008, s. 11). Warto podkreślić, że wykluczenie finansowe w obszarze bankowości transakcyjnej może być stopniowane ze względu na zakres i intensywność wykorzystania różnych typów usług przez konsumentów. Dlatego Komisja Europejska zwraca uwagę na kilka poziomów wykluczenia finansowego (Kurczewska, 2011, s. 55): pierwszy dotyczy osób, które nie korzystają w ogóle z usług bankowych; drugi odnosi się do osób, które posiadają rachunek bankowy, lecz nie wykorzystują wielu jego opcji (np. nie korzystają z elektronicznych usług bankowych czy kart płatniczych lub kredytowych); trzeci związany jest z osobami mającymi dostęp do szerokiego wachlarza usług bankowych, lecz usługi te nie są w pełni dostosowane do potrzeb i statusu społeczno-ekonomicznego tych osób.

W oparciu o zaprezentowane definicje można przyjąć, że transakcyjne wykluczenie finansowe oznacza stan, w którym osoby lub grupy społeczne doświadczają braku lub ograniczenia w dostępie do usług bankowych, takich jak: rachunek bankowy, jego funkcjonalności, usługi bankowości elektronicznej czy karty płatnicze (Nowacka, 2019, s. 297). Skala i intensywność tego zjawiska mogą być określane w oparciu o poziomy ubankowienia (European Commission, 2008, s. 15; Maison, 2017, s. 6-7; Polasik \& Piotrowska, 2014, s. 319). Mając na względzie systematykę poziomów ubankowienia oraz włączenie konsumentów w obszar bankowości transakcyjnej, można wyróżnić kilka poziomów transakcyjnego wykluczenia finansowego (schemat 2).

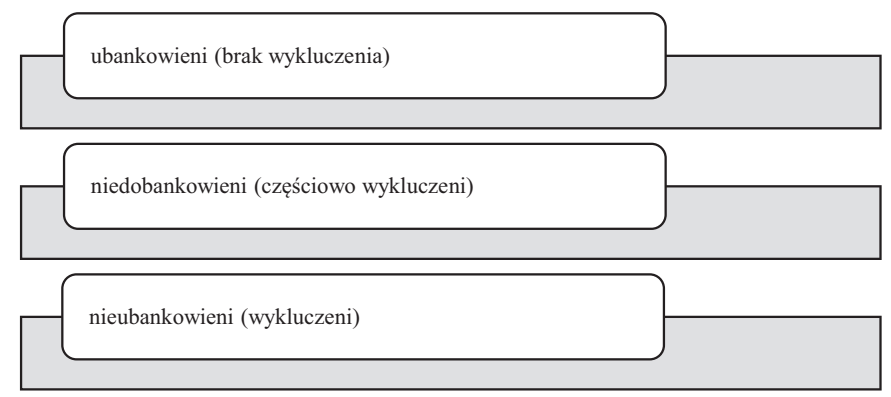

Schemat 2. Poziomy transakcyjnego wykluczenia finansowego

Źródło: opracowanie własne.

Poziomy transakcyjnego wykluczenia finansowego są związane z intensywnością korzystania z usług bankowych, w szczególności zaś z posiadaniem rachunku bankowego i wykorzystywaniem jego funkcjonalności:

- nieubankowieni (wykluczeni) to osoby nieposiadające rachunku bankowego i niekorzystające $\mathrm{z}$ innych usług bankowych, 
- niedobankowieni (częściowo wykluczeni) to osoby posiadające rachunek bankowy, ale niekorzystające lub korzystające w niewielkim zakresie z kart płatniczych i bankowości elektronicznej albo osoby nieposiadające własnego rachunku bankowego, ale korzystające z pozostałych usług,

- ubankowieni (brak wykluczenia) to osoby posiadające rachunek bankowy oraz korzystające z kart płatniczych i bankowości elektronicznej.

\section{Cel i hipotezy badawcze}

Przegląd prac badawczych plasujących się w szeroko rozumianej literaturze przedmiotu wskazuje, że tematyka przeprowadzonych dotychczas badań empirycznych dotyczyła wpływu edukacji finansowej w obszarze zarządzania finansami osobistymi na ograniczanie wykluczenia finansowego. Brakuje pogłębionej analizy uwzględniającej poszczególne rodzaje wykluczenia finansowego, np. transakcyjnego w odniesieniu do osób szczególnie narażonych na występowanie tego zjawiska. Taką grupę stanowią osoby bezrobotne. Powyższe przesłanki stanowiły przyczynek do podjęcia badań empirycznych w zakresie wspomnianej tematyki.

Celem opracowania jest określenie stosunku osób bezrobotnych do edukacji finansowej w obszarze zarządzania finansami osobistymi w zależności od poziomu transakcyjnego wykluczenia finansowego. $Z$ uwagi na aktualność podejmowanej problematyki oraz analizę literatury przedmiotu i przedstawiony cel opracowania sformułowano następujące hipotezy:

H1. Postawy wobec edukacji finansowej w obszarze zarządzania finansami osobistymi są związane z wybranymi cechami społeczno-demograficznymi (płcią, wiekiem, wykształceniem, okresem zarejestrowania w urzędzie pracy) osób bezrobotnych.

H2. Ocena umiejętności finansowych w zakresie sposobu zarządzania finansami osobistymi jest związana z poziomem ubankowienia (stopniem transakcyjnego wykluczenia finansowego) osób bezrobotnych.

H3. Postawy wobec edukacji finansowej w obszarze zarządzania finansami osobistymi są zależne od poziomu ubankowienia (stopnia transakcyjnego wykluczenia finansowego) osób bezrobotnych.

Materiał empiryczny wykorzystany do weryfikacji hipotez został zebrany w wyniku przeprowadzonego badania ankietowego.

\section{Metody i zakres przeprowadzonych badań}

Badanie empiryczne zostało zrealizowane $\mathrm{w}$ formie kwestionariusza ankiety, który został opracowany samodzielnie. Grupą docelową były osoby bezrobotne zarejestrowane w Miejskim Urzędzie Pracy w Płocku. Według stanu na koniec sierpnia 2018 roku w rejestrze bezrobotnych MUP w Płocku było zarejestrowanych 4319 osób 
(MUP w Płocku, 2019, s. 1). Łącznie badaniem zostało objętych 350 bezrobotnych, co pozwoliło uzyskać próbę reprezentatywną umożliwiającą wnioskowanie o całej populacji bezrobotnych w Płocku z dokładnością do 5\%. Osoby objęte badaniem ankietowym zostały wybrane metodą doboru wygodnego (Hill \& Aleksander, 2003, s. 126). O wypełnienie ankiety poproszono bezrobotnych, którzy wyrazili chęć udzielenia odpowiedzi na zawarte w kwestionariuszu pytania. Badanie zostało przeprowadzone w okresie wrzesień-październik 2018 roku.

Kwestionariusz ankiety składał się z 20 pytań zamkniętych. Dotyczyły one rodzajów wykluczenia finansowego oraz stosunku do usług finansowych i edukacji finansowej $\mathrm{w}$ obszarze zarządzania finansami osobistymi. Odpowiedzi na pytania zawarte w ankiecie udzieliło 350 osób bezrobotnych zarejestrowanych w Miejskim Urzędzie Pracy w Płocku.

\section{Metody opracowania wyników badania}

Jako próg istotności statystycznej konwencjonalnie przyjęto wartość 0,05 . Istotność statystyczną analizowanych zależności badano w oparciu o wartości ilorazu wiarygodności, który służy do analizowania zależności pomiędzy zmiennymi kategorialnymi, jakościowymi. W odróżnieniu od klasycznego testu niezależności $\chi^{2}$ prawidłowo oszacowuje istotność statystyczną, nawet jeżeli analizowane kategorie są mało liczne, tzn. w tym przypadku, jeżeli niektóre spośród analizowanych odpowiedzi były zaznaczone przez niewielką liczbę osób badanych. Istotna statystycznie wartość ilorazu wiarygodności oznacza, że pomiędzy analizowanymi zmiennymi kategorialnymi zachodzi zależność. Za pomocą tego testu analizowano zależności pomiędzy stopniem ubankowienia (stopniem transakcyjnego wykluczenia finansowego) a stosunkiem do edukacji finansowej w obszarze zarządzania finansami osobistymi. Ponieważ osoby badane określiły swoje umiejętności z zakresu zarządzania finansami osobistymi oraz wyraziły opinie na temat edukacji finansowej, odpowiadając na pytania wielokrotnego wyboru, iloraz wiarygodności obliczono dla każdej możliwej odpowiedzi.

Ponadto istotne statystycznie zależności uzupełniono wartościami miar siły efektu V Cramera. Interpretacja wartości tej miary zależy od liczby osób badanych i liczby porównywanych grup. Informacja o tych danych jest zawarta w parametrze nazwanym liczbą stopni swobody, podawanym w nawiasach przy wartościach miary V Cramera.

\section{Weryfikacja hipotezy H1}

Jednym z elementów badania ankietowego było zbadanie postaw respondentów wobec edukacji finansowej w obszarze zarządzania finansami osobistymi. Do weryfikacji hipotezy H1 wykorzystano pytanie wielokrotnego wyboru określa- 
jące stosunek do edukacji finansowej, rozumianej jako opinie na temat edukacji w obszarze zarządzania finansami osobistymi. Kafeteria odpowiedzi obejmowała następujące warianty wynikające $\mathrm{z}$ definicji zarządzania finansami osobistymi: (1) edukacja finansowa zapewnia lepsze zrozumienie usług finansowych; (2) edukacja finansowa zapewnia lepsze zrozumienie ryzyka i korzyści płynących z korzystania z usług finansowych (np. kredytów); (3) edukacja finansowa przyczynia się do lepszego zarządzania finansami osobistymi; (4) edukacja finansowa przyczynia się do podejmowania trafnych decyzji w zakresie zarządzania domowym budżetem; (5) edukacja finansowa nie przyczynia się do lepszego zarządzania finansami osobistymi. Drugie pytanie z metryczki dotyczyło następujących cech: wiek, wykształcenie, okres zarejestrowania w urzędzie pracy. Rozkład odpowiedzi i wyników analizy zaprezentowano na rysunkach 1-3 oraz w tabeli 2 .

Tabela 2. Analiza zależności pomiędzy cechami społeczno-demograficznymi (płeć, wiek, wykształcenie, okres zarejestrowania w urzędzie pracy) a opiniami na temat edukacji finansowej w obszarze zarządzania finansami osobistymi

\begin{tabular}{|c|c|c|c|c|}
\hline $\begin{array}{l}\text { Cechy społeczno- } \\
\text {-demograficzne }\end{array}$ & $\begin{array}{l}\text { Edukacja finansowa w obszarze zarządzania } \\
\text { finansami osobistymi }\end{array}$ & $\chi$ & df & $\mathrm{p}$ \\
\hline \multirow{5}{*}{ Płeć } & Zapewnia lepsze zrozumienie usług finansowych & 0,6 & 2 & 0,742 \\
\hline & Zapewnia lepsze zrozumienie ryzyka i korzyści & 0,94 & 2 & 0,625 \\
\hline & Przyczynia się do lepszego zarządzania finansami osobistymi & 2,23 & 2 & 0,328 \\
\hline & Przyczynia się do podejmowania trafnych decyzji & 3,54 & 2 & 0,170 \\
\hline & $\begin{array}{l}\text { Nie przyczynia się do lepszego zarządzania finansami } \\
\text { osobistymi }\end{array}$ & 1,23 & 2 & 0,542 \\
\hline \multirow{5}{*}{ Wiek } & Zapewnia lepsze zrozumienie usług finansowych & 13,51 & 8 & 0,095 \\
\hline & Zapewnia lepsze zrozumienie ryzyka i korzyści & 7,71 & 8 & 0,462 \\
\hline & Przyczynia się do lepszego zarządzania finansami osobistymi & 14,30 & 8 & 0,074 \\
\hline & Przyczynia się do podejmowania trafnych decyzji & 17,63 & 8 & 0,024 \\
\hline & $\begin{array}{l}\text { Nie przyczynia się do lepszego zarządzania finansami } \\
\text { osobistymi }\end{array}$ & 15,55 & 8 & 0,049 \\
\hline \multirow{5}{*}{ Wykształcenie } & Zapewnia lepsze zrozumienie usług finansowych & 7,45 & 6 & 0,281 \\
\hline & Zapewnia lepsze zrozumienie ryzyka i korzyści & 12,42 & 6 & 0,053 \\
\hline & Przyczynia się do lepszego zarządzania finansami osobistymi & 11,31 & 6 & 0,079 \\
\hline & Przyczynia się do podejmowania trafnych decyzji & 9,95 & 6 & 0,127 \\
\hline & $\begin{array}{l}\text { Nie przyczynia się do lepszego zarządzania finansami } \\
\text { osobistymi }\end{array}$ & 14,10 & 6 & 0,029 \\
\hline \multirow{5}{*}{$\begin{array}{l}\text { Okres } \\
\text { zarejestrowania } \\
\text { w urzędzie pracy }\end{array}$} & Zapewnia lepsze zrozumienie usług finansowych & 1,95 & 4 & 0,745 \\
\hline & Zapewnia lepsze zrozumienie ryzyka i korzyści & 2,48 & 4 & 0,648 \\
\hline & Przyczynia się do lepszego zarządzania finansami osobistymi & 11,11 & 4 & 0,025 \\
\hline & Przyczynia się do podejmowania trafnych decyzji & 2,65 & 4 & 0,618 \\
\hline & $\begin{array}{l}\text { Nie przyczynia się do lepszego zarządzania finansami } \\
\text { osobistymi }\end{array}$ & 3,73 & 4 & 0,444 \\
\hline
\end{tabular}

$\chi$ - wartość ilorazu wiarygodności; df - liczba stopni swobody; $\mathrm{p}$ - istotność statystyczna

Źródło: opracowanie własne. 
Spośród zestawu cech społeczno-demograficznych stwierdzono istotne statystycznie zależności pomiędzy opiniami na temat edukacji finansowej w obszarze zarządzania finansami osobistymi a następującymi cechami: wiek, wykształcenie, okres zarejestrowania w urzędzie pracy.

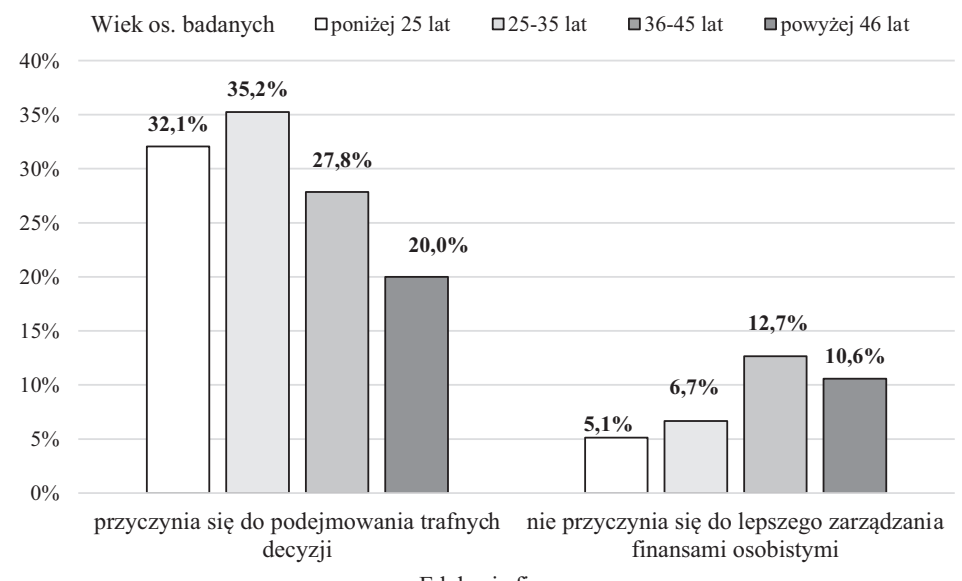

Rysunek 1. Zależność pomiędzy opiniami na temat edukacji finansowej w obszarze zarządzania finansami osobistymi a wiekiem osób badanych

Źródło: opracowanie własne.

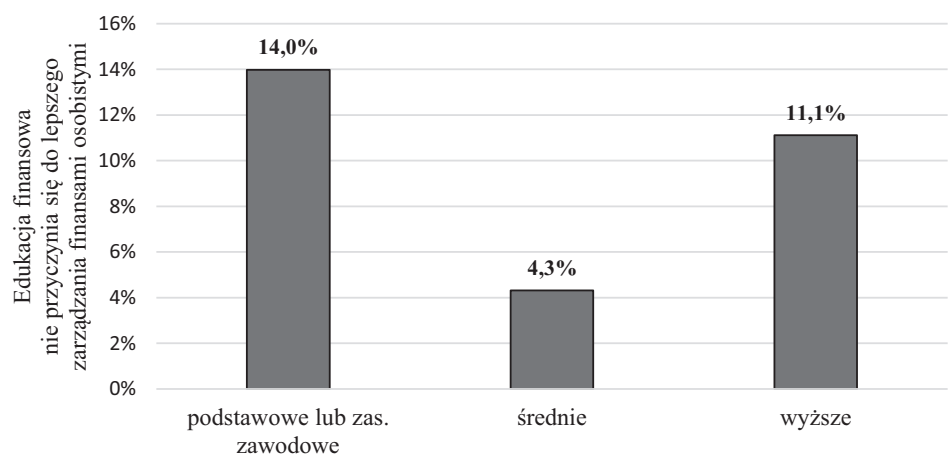

Wykształcenie

Rysunek 2. Zależność pomiędzy opiniami na temat edukacji finansowej w obszarze zarządzania finansami osobistymi a wykształceniem osób badanych

Źródło: opracowanie własne. 


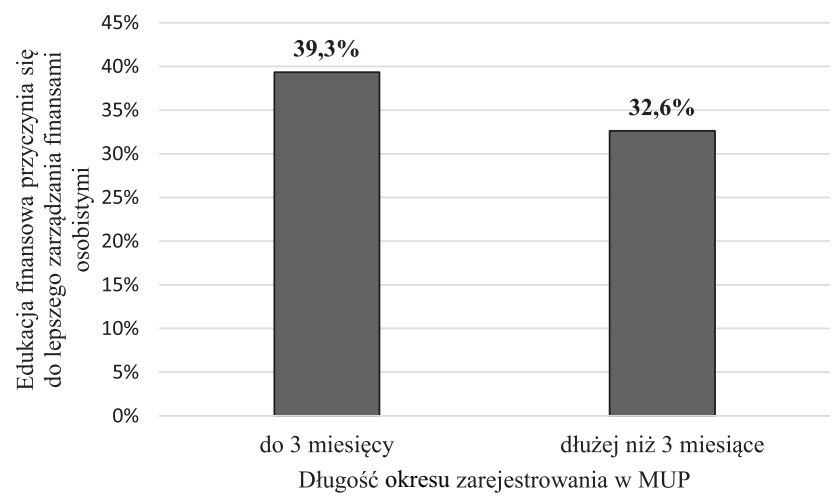

Rysunek 3. Zależność pomiędzy opiniami na temat edukacji finansowej w obszarze zarządzania finansami osobistymi a okresem zarejestrowania w urzędzie pracy osób badanych

Źródło: opracowanie własne.

Opinia, że edukacja finansowa w obszarze zarządzania finansami osobistymi przyczynia się do podejmowania trafnych decyzji, była najczęstsza $\mathrm{w}$ grupie wiekowej 25-35 lat, $V(8)=0,16, \mathrm{p}<0,05$.

Natomiast przekonanie, że edukacja finansowa nie przyczynia się do lepszego zarządzania finansami osobistymi występowało częściej w grupie wiekowej 36-45 lat, $V(8)=0,15, \mathrm{p}<0,05$ (rysunek 1). Podobną postawę prezentowali respondenci z wykształceniem podstawowym i zasadniczym zawodowym $\mathrm{V}(6)=0,13, \mathrm{p}=0,077$ (rysunek 2).

Opinię, że edukacja finansowa przyczynia się do lepszego zarządzania finansami osobistymi częściej podzielały osoby z krótszym okresem zarejestrowania w urzędzie pracy $\mathrm{V}(4)=0,13, \mathrm{p}<0,05$ (rysunek 3 ).

Przedstawione wyniki badania ankietowego wskazują, że bardziej negatywna postawa wobec znaczenia edukacji finansowej w procesie zarządzania finansami osobistymi występowała $\mathrm{w}$ grupie wiekowej 36-45 lat, z wykształceniem podstawowym i zasadniczym zawodowym. Walory pogłębiania wiedzy w tym zakresie częściej dostrzegały osoby młodsze, z krótszym stażem osób bezrobotnych.

Analiza wyników badania pozwala skonstatować, że istnieje zależność między pewnymi cechami społeczno-demograficznymi (wiek, wykształcenie, okres zarejestrowania $\mathrm{w}$ urzędzie pracy) a opinią na temat edukacji finansowej w obszarze zarządzania finansami osobistymi. Należy dodać, że siła otrzymanego efektu miała charakter umiarkowany. Nie stwierdzono istotnej statystycznie zależności między cechą płeć a stosunkiem do edukacji finansowej w obszarze zarządzania finansami osobistymi. Potwierdza to z jednej strony, że trudno jednoznacznie wskazać grupę osób bezrobotnych posiadającą określone cechy, która będzie prezentować pozytywną lub negatywną postawę wobec edukacji finansowej w obszarze zarządzania finansami osobistymi. Z drugiej strony nie można stwierdzić, że wymienione cechy nie mają żadnego wpływu na kształtowanie opinii na temat edukacji finansowej w obszarze zarządzania finansami osobistymi. 
Można zatem uznać hipotezę H1 za prawdziwą i wnioskować, że postawy wobec edukacji finansowej w obszarze zarządzania finansami osobistymi są związane z wybranymi cechami społeczno-demograficznymi osób bezrobotnych (takimi jak wiek, wykształcenie i okres zarejestrowania w urzędzie pracy).

\section{Weryfikacja hipotezy $\mathrm{H} 2$}

Do weryfikacji hipotezy H2 wykorzystano pytanie wielokrotnego wyboru dotyczące oceny umiejętności finansowych w zakresie sposobu zarządzania finansami osobistymi. Kafeteria odpowiedzi obejmowała następujące warianty ustalone na podstawie definicji zarządzania finansami osobistymi, odnoszące się do umiejętności finansowych: (1) bardzo dobrze potrafię analizować, oceniać i podejmować trafne decyzje w zakresie zarządzania domowym budżetem; (2) potrafię zarządzać finansami osobistymi, ale decyzje finansowe nie zawsze są właściwe; (3) nie zarządzam finansami, decyzje podejmuję spontanicznie; (4) decyzje finansowe podejmuję pod wpływem reklam, sugestii znajomych, pracowników instytucji finansowych; (5) nie zarządzam finansami w moim gospodarstwie domowym i nie podejmuję decyzji finansowych. Drugie pytanie dotyczyło zakresu usług bankowych, z których korzystają klienci. Wyodrębniono w nim trzy poziomy ubankowienia: nieubankowieni (niekorzystający z żadnych usług bankowych), niedobankowieni (korzystający tylko z rachunku ROR) oraz ubankowieni (korzystający z rachunku ROR, kart płatniczych oraz bankowości elektronicznej). Wyniki analizy zaprezentowano w tabeli 3.

Tabela 3. Analiza zależności pomiędzy oceną umiejętności finansowych i sposobu zarządzania finansami osobistymi a poziomami ubankowienia (stopniem transakcyjnego wykluczenia finansowego)

\begin{tabular}{|c|c|c|c|c|c|c|}
\hline $\begin{array}{c}\text { Ocena umiejętności finansowych } \\
\text { i sposobu zarządzania finansami } \\
\text { osobistymi }\end{array}$ & Nieubankowieni & Niedobankowieni & Ubankowieni & $\chi$ & df & $\mathrm{p}$ \\
\hline $\begin{array}{l}\text { Bardzo dobrze potrafię analizować, } \\
\text { oceniać i podejmować trafne decyzje } \\
\text { w zakresie zarządzania domowym } \\
\text { budżetem }\end{array}$ & 7 & 32 & 32 & 7,09 & 6 & 0,313 \\
\hline $\begin{array}{l}\text { Potrafię zarządzać finansami osobisty- } \\
\text { mi, ale decyzje finansowe nie zawsze } \\
\text { są właściwe }\end{array}$ & 5 & 44 & 36 & 4,09 & 6 & 0,665 \\
\hline $\begin{array}{l}\text { Nie zarządzam finansami, decyzje } \\
\text { podejmuję spontanicznie }\end{array}$ & 0 & 10 & 4 & 7,68 & 6 & 0,262 \\
\hline $\begin{array}{l}\text { Decyzje finansowe podejmuję pod } \\
\text { wpływem reklam, sugestii znajomych, } \\
\text { pracowników instytucji finansowych }\end{array}$ & 1 & 6 & 7 & 4,01 & 6 & 0,676 \\
\hline $\begin{array}{l}\text { Nie zarządzam finansami w moim } \\
\text { gospodarstwie domowym i nie podej- } \\
\text { muję decyzji finansowych }\end{array}$ & 1 & 8 & 2 & 5,59 & 6 & 0,471 \\
\hline
\end{tabular}

$\chi$ - wartość ilorazu wiarygodności; df - liczba stopni swobody; $\mathrm{p}$ - istotność statystyczna

Źródło: opracowanie własne. 
Nie otrzymano istotnych statystycznie zależności pomiędzy przynależnością do wyodrębnionych grup o różnym stopniu ubankowienia (poziomie transakcyjnego wykluczenia finansowego) a ocenami umiejętności finansowych w zakresie sposobu zarządzania finansami osobistymi.

Konkludując, należy zauważyć, że zaprezentowane wyniki badania nie pozwalają na uznanie hipotezy H2 za prawdziwą. To oznacza, że ocena umiejętności finansowych w zakresie sposobu zarządzania finansami osobistymi nie jest związana z poziomem ubankowienia (stopniem transakcyjnego wykluczenia finansowego) osób bezrobotnych.

\section{Weryfikacja hipotezy $\mathrm{H3}$}

Do weryfikacji hipotezy H3 wykorzystano pytanie kwestionariusza, w którym poproszono respondentów o opinię na temat edukacji finansowej w obszarze zarządzania finansami osobistymi. Osoby objęte badaniem mogły udzielać odpowiedzi w oparciu o następujące warianty ustalone na podstawie definicji zarządzania finansami osobistymi: (1) edukacja finansowa zapewnia lepsze zrozumienie usług finansowych; (2) edukacja finansowa zapewnia lepsze zrozumienie ryzyka i korzyści płynących z korzystania z usług finansowych (np. kredytów); (3) edukacja finansowa przyczynia się do lepszego zarządzania finansami osobistymi; (4) edukacja finansowa przyczynia się do podejmowania trafnych decyzji w zakresie zarządzania domowym budżetem; (5) edukacja finansowa nie przyczynia się do lepszego zarządzania finansami osobistymi. Drugie pytanie dotyczyło zakresu usług bankowych, z których korzystają klienci. Wyodrębniono w nim trzy poziomy ubankowienia: nieubankowieni (niekorzystający z żadnych usług bankowych), niedobankowieni (korzystający tylko z rachunku ROR) oraz ubankowieni (korzystający z rachunku ROR, kart płatniczych oraz bankowości elektronicznej). Rozkład odpowiedzi i wyników analizy zaprezentowano na rysunkach 4-7 oraz w tabeli 4.

Tabela 4. Analiza zależności pomiędzy opiniami na temat edukacji finansowej w obszarze zarządzania finansami osobistymi a poziomami ubankowienia (stopniem transakcyjnego wykluczenia finansowego)

\begin{tabular}{|l|c|c|c|c|c|c|}
\hline \multicolumn{1}{|c|}{ Edukacja finansowa } & Nieubankowieni & Niedobankowieni & Ubankowieni & $\chi$ & $\mathrm{df}$ & $\mathrm{p}$ \\
\hline $\begin{array}{l}\text { Zapewnia lepsze zrozumienie usług } \\
\text { finansowych }\end{array}$ & 4 & 30 & 37 & 12,34 & 6 & 0,055 \\
\hline $\begin{array}{l}\text { Zapewnia lepsze zrozumienie } \\
\text { ryzyka i korzyści }\end{array}$ & 3 & 40 & 43 & 24,96 & 6 & 0,001 \\
\hline $\begin{array}{l}\text { Przyczynia się do lepszego zarzą- } \\
\text { dzania finansami osobistymi }\end{array}$ & 5 & 27 & 39 & 20,08 & 6 & 0,003 \\
\hline $\begin{array}{l}\text { Przyczynia się do podejmowania } \\
\text { trafnych decyzji }\end{array}$ & 1 & 24 & 33 & 22,44 & 6 & 0,001 \\
\hline $\begin{array}{l}\text { Nie przyczynia się do lepszego } \\
\text { zarządzania finansami osobistymi }\end{array}$ & 2 & 7 & 9 & 13,92 & 6 & 0,031 \\
\hline
\end{tabular}

\footnotetext{
$\chi$ - wartość ilorazu wiarygodności; df - liczba stopni swobody; $\mathrm{p}$ - istotność statystyczna Źródło: opracowanie własne.
} 


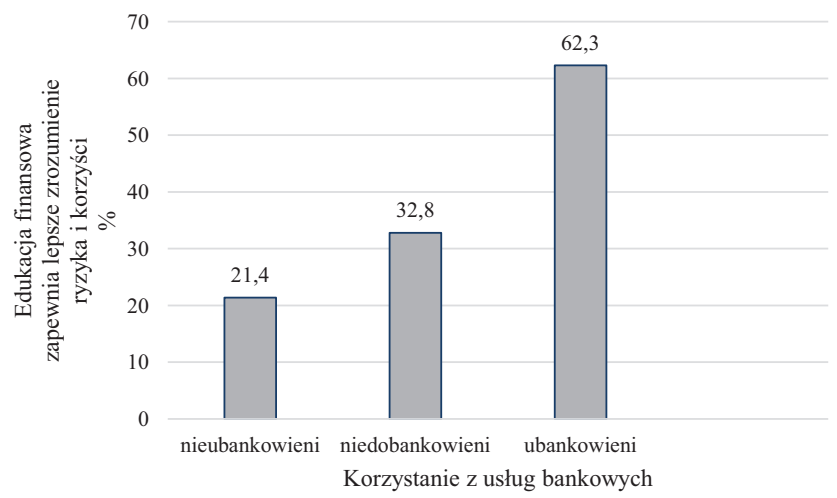

Rysunek 4. Zależność pomiędzy opinią, że edukacja finansowa w obszarze zarządzania finansami osobistymi zapewnia lepsze zrozumienie ryzyka i korzyści a poziomem ubankowienia (stopniem transakcyjnego wykluczenia finansowego)

Źródło: opracowanie własne.

W oparciu o test porównań parami stwierdzono, że opinia, według której edukacja finansowa w obszarze zarządzania finansami osobistymi zapewnia lepsze zrozumienie ryzyka i korzyści, była istotnie statystycznie częstsza w grupie osób, które korzystały z ROR, karty bankowej i bankowości elektronicznej niż w grupie osób, które nie korzystały $\mathrm{z}$ analizowanych usług bankowych, $\lambda(1)=6,31, \mathrm{p}<0,05$. Podobną zależność zaobserwowano $\mathrm{w}$ grupie osób bezrobotnych, które korzystały z ROR, karty bankowej i bankowości elektronicznej, $\lambda(2)=16,65, \mathrm{p}<0,001$ (rysunek 4).

Przekonanie, że edukacja finansowa przyczynia się do lepszego zarządzania finansami osobistymi, istotnie statystycznie częściej występowało w grupie osób, które korzystały z ROR, karty bankowej i bankowości elektronicznej niż w grupie osób, które korzystały tylko z ROR, $\lambda(2)=16,50, \mathrm{p}<0,001$ (rysunek 5).

Osoby ubankowione istotnie statystycznie częściej twierdziły, że edukacja finansowa $\mathrm{w}$ obszarze zarządzania finansami osobistymi przyczynia się do podejmowania trafnych decyzji niż osoby nieubankowione, $\lambda(1)=9,61, \mathrm{p}<0,01$, a także osoby niedobankowione, $\lambda(2)=12,67, \mathrm{p}<0,01$ (rysunek 6).

Opinia, że edukacja finansowa nie przyczynia się do lepszego zarządzania finansami osobistymi była istotnie statystycznie częstsza w grupie osób, które nie korzystały z usług bankowych niż w grupie osób, które korzystały tylko z ROR, $\lambda(2)=11,57, \mathrm{p}<0,01$ (rysunek 7).

Przedstawione wyniki badania pozwalają skonstatować, że istnieje zależność między poziomem ubankowienia a stosunkiem do edukacji finansowej w obszarze zarządzania finansami osobistymi. Im większy stopień transakcyjnego wykluczenia finansowego, tym bardziej negatywny stosunek do edukacji finansowej w obszarze zarządzania finansami osobistymi. To oznacza, że osoby wykluczone finansowo w obszarze transakcyjnym częściej nie dostrzegały pozytywnych aspektów pogłębiania wiedzy w zakresie zarządzania finansami osobistymi. Zalety edukacji 


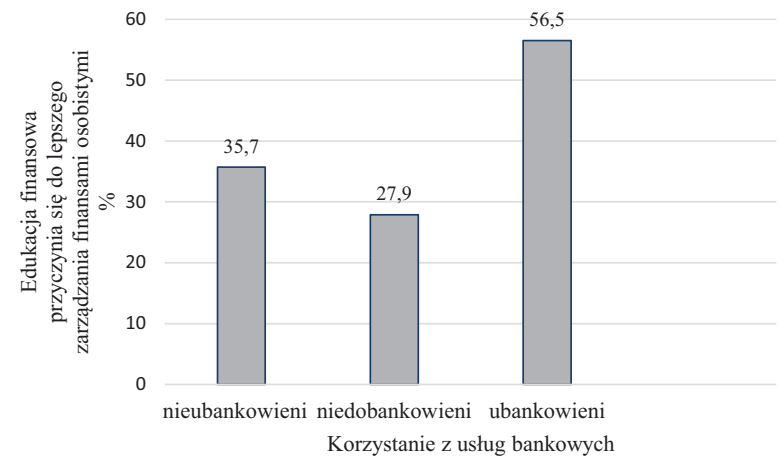

Rysunek 5. Zależność pomiędzy opinią, że edukacja finansowa przyczynia się do lepszego zarządzania finansami osobistymi a poziomem ubankowienia (stopniem transakcyjnego wykluczenia finansowego)

Źródło: opracowanie własne.

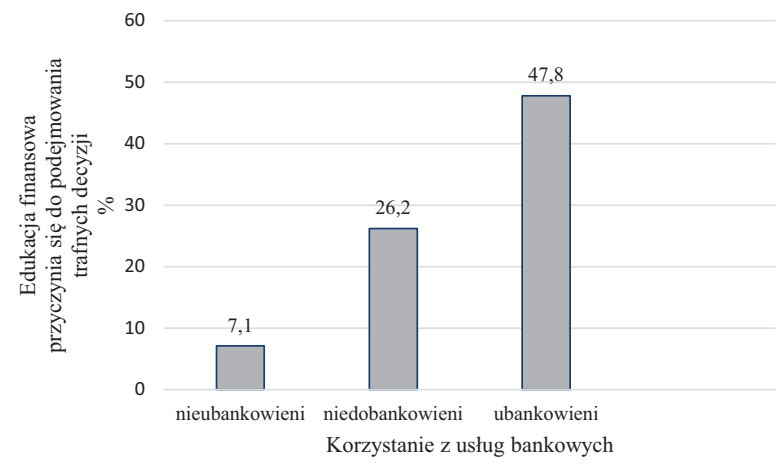

Rysunek 6. Zależność pomiędzy opinią, że edukacja finansowa w obszarze zarządzania finansami osobistymi przyczynia się do podejmowania trafnych decyzji a poziomem ubankowienia (stopniem transakcyjnego wykluczenia finansowego)

Źródło: opracowanie własne.

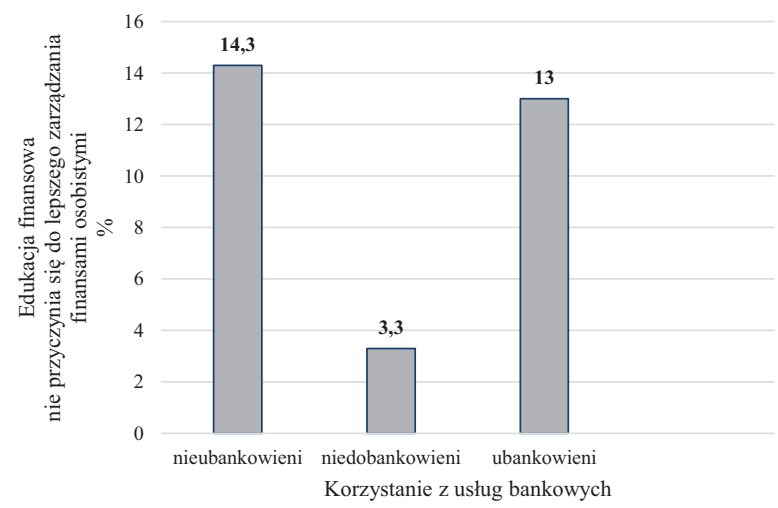

Rysunek 7. Zależność pomiędzy opinią, że edukacja finansowa nie przyczynia się do lepszego zarządzania finansami osobistymi a poziomem ubankowienia (stopniem transakcyjnego wykluczenia finansowego)

Źródło: opracowanie własne. 
finansowej w obszarze zarządzania finansami osobistymi częściej podkreślały osoby ubankowione.

Reasumując, można uznać hipotezę H3 za prawdziwą i stwierdzić, że postawy wobec edukacji finansowej w obszarze zarządzania finansami osobistymi są zależne od poziomu ubankowienia (stopnia transakcyjnego wykluczenia finansowego) osób bezrobotnych.

\section{Zakończenie}

Edukacja finansowa to narzędzie wspierające racjonalne decyzje finansowe oraz metoda wspomagająca zarządzanie finansami osobistymi, utożsamianymi z budżetem domowym. Analiza literatury przedmiotu oraz wyników badania ankietowego wskazuje, że istnieje potrzeba pogłębiania wiedzy finansowej, szczególnie w grupach narażonych w większym stopniu na transakcyjne wykluczenie finansowe.

Zastosowanie różnych metod statystycznych do analizy danych empirycznych pozyskanych w wyniku badania ankietowego pozwoliło na częściowo pozytywne zweryfikowanie hipotez badawczych. Tym samym można uznać, że stosunek do edukacji finansowej w obszarze zarządzania finansami osobistymi jest determinowany wybranymi cechami społeczno-demograficznymi (takimi jak wiek, wykształcenie i okres zarejestrowania w urzędzie pracy) oraz poziomem transakcyjnego wykluczenia finansowego (określanego poziomem ubankowienia). To oznacza, że osoby bezrobotne, które w większym stopniu korzystają z usług bankowych, częściej dostrzegają potrzebę pogłębiania wiedzy finansowej. Warto zwrócić uwagę, że płeć jest tym czynnikiem, który nie wpływa na kształtowanie postaw wobec edukacji finansowej w obszarze zarządzania finansami osobistymi.

Jednocześnie otrzymane wyniki badania pokazują, że ocena umiejętności finansowych w zakresie sposobu zarządzania finansami osobistymi nie jest determinowana poziomem ubankowienia (stopniem transakcyjnego wykluczenia finansowego) osób bezrobotnych. Trzeba podkreślić, że ocena ta miała charakter subiektywny. Dlatego celowe wydaje się podjęcie w kolejnych badaniach próby oceny wiedzy finansowej, a w odniesieniu do zarządzania budżetem domowym - poprzez pytania kontrolne $\mathrm{z}$ tego zakresu.

W świetle przedstawionych faktów można stwierdzić, że osoby bezrobotne w Płocku prezentują różny poziom ubankowienia, a tym samym są dotknięte transakcyjnym wykluczeniem finansowym w różnym stopniu. Zidentyfikowanie czynników determinujących stosunek do edukacji finansowej w obszarze zarządzania finansami osobistymi pozwala na wskazanie kierunku działań inkluzyjnych zmierzających do ograniczenia zjawiska ekskluzji finansowej. Zasadne wydaje się więc podnoszenie świadomości finansowej poprzez kampanie społeczne, dedykowane szkolenia i warsztaty oraz współpracę z bankami i instytucjami finansowymi w tym zakresie, a także podejmowanie programów wsparcia dla osób zadłużonych. Programy edu- 
kacyjne z zakresu finansów mogą przyczynić się do ograniczenia poziomu wykluczenia finansowego, a tym samym wpłynąć na zmniejszenie wydatków związanych ze świadczeniami z opieki społecznej.

\section{Bibliografia}

Atkinson, A., \& Messy, F. (2012). Measuring Financial Literacy: Results of the OECD / International Network on Financial Education (INFE) Pilot Study. OECD Working Papers on Finance, Insurance and Private Pensions, (15), 1-72. doi:10.1787/20797117

Barembruch, A. (2012). Zarządzanie finansami osobistymi. Zeszyty Naukowe Uniwersytetu Szczecińskiego. Finanse. Rynki Finansowe. Ubezpieczenia. (50), 239-248.

Campbell, J.Y. (2006). Household finance. The Journal of Finance, 61(4), 1553-1604. doi:10.1111/j.1540-6261.2006.00883.x

Cohen, M., \& Nelson, C. (2011). Financial Literacy: A Step for Clients towards Financial Inclusion. Global Microcredit Summit, Valladolid, Spain. Pobrane z: https:/citeseerx.ist.psu.edu/viewdoc/download?doi $=10.1 .1 .466 .2029 \&$ rep $=$ rep1\&type $=$ pdf

Demirguc-Kunt, A., Klapper, L., \& Singer, D. (2017). Financial inclusion and inclusive growth - A review of recent empirical evidence. World Bank Policy Research Paper, (8040). doi:10.1596/1813-9450-8040

European Commission. (2008). Financial Services Provision and Prevention of Financial Exclusion, March. Pobrane z: www.fi-compass.eu/publication/other-resources/financial-services-provision-and-prevention-financial-exclusion

Frączek, B. (2014). Obszary badań w zakresie poziomu wiedzy i edukacji finansowej społeczeństwa w Polsce i na świecie. Studia Ekonomiczne - Zeszyty Naukowe Uniwersytetu Ekonomicznego w Katowicach, 1(173), 118-128.

Garman, E.T., \& Forgue, R. (2008). Personal Finance. USA: Houghton Mifflin Company.

Hilgert, M.A., Hogarth, J.M., \& Beverly, S.G. (2003). Household Financial Management: The Connection between Knowledge and Behavior. Federal Reserve Bulletin. July. Pobrane z: www.federalreserve. gov/pubs/bulletin/2003/0703lead.pdf

Hill, N., \&Alexander, J. (2003). Pomiar satysfakcji i lojalności klientów. Kraków: Oficyna Ekonomiczna.

Iwanicz-Drozdowska, M. (red.). (2009). Produkty finansowe i edukacja finansowa w Polsce na tle wybranych krajów wysoko rozwiniętych. Raport z badań. Warszawa: SGH.

Kłopocka, A. (2018). Skłonność gospodarstw domowych do oszczędzania a wiedza finansowa. Bank $i$ Kre$d y t, 49(5)$. Pobrane z: https://bankikredyt.nbp.pl/content/2018/05/BIK_05_2018_02.pdf

Korenik, D., \& Korenik, S. (2004). Podstawy finansów. Warszawa: PWN.

Kurczewska, A. (2011). Społeczna odpowiedzialność instytucji mikrokredytowych w Europie. W: B. Mikołajczyk, A. Kurczewska (red.), Mikrokredyty w Europie sposobem na pobudzenie przedsiębiorczości $i$ walkę z wykluczeniem społecznym (s. 52-64). Warszawa: Difin.

Lusardi, A., \& Mitchell, O.S. (2011a). Financial Literacy and Planning: Implications for Retirement Wellbeing. W: O.S. Mitchell, A. Lusardi (eds.), Financial Literacy: Implications for Retirement Security and the Financial Marketplace (s. 2-37). Oxford: Oxford University Press. doi:10.3386/w17078

Lusardi, A., \& Mitchell, O.S. (2011b). The outlook for financial literacy. W: O.S. Mitchell, A. Lusardi (eds.), Financial Literacy: Implications for Retirement Security and the Financial Marketplace (s. 2-19). Oxford: Oxford University Press.

Lusardi, A., \& Mitchell, O.S. (2014). The economic importance of financial literacy: Theory and evidence. Journal of Economic Literature, 52(1), 5-44. doi:10.1257/jel.52.1.5

Maison, D. (2017). Postawy Polaków wobec obrotu bezgotówkowego. Raport. Warszawa: NBP.

MUP w Płocku. (2019). Sprawozdanie o rynku pracy 01.08.2018-31.08.2018. Pobrane z: http://mupplock. praca.gov.pl/documents/4063619/6455409/MRPiPS-01\%2008.2018.pdf/6698b386-c77a-487d-8b59ca35a9ef60dc?t=1536920094755 
Musiał, M. (2016). Znaczenie wiedzy finansowej w procesie zarządzania finansami osobistymi. Finanse i Prawo Finansowe, (1), 97-108.

Nowacka, A. (2019). Financial exclusion of a transactional character: case study of the unemployed in the city of Plock. W: A. Auzina (ed.), Economic Science for Rural Development (s. 296-301). Jelgava: Latvia University of Life Sciences and Technologies. doi:10.22616/ESRD.2019.135

OECD. (2016). G20/OECD INFE core competencies framework on financial literacy for adults. International Survey of Adult Financial Literacy Competencies.

Orzeszko, T. (2014). Miejsce edukacji finansowej społeczeństwa w strategii społecznej odpowiedzialności biznesu krajowych banków giełdowych w Polsce. Prace Naukowe Uniwersytetu Ekonomicznego we Wroctawiu, (330), 274-283. doi:10.15611/pn.2014.330.29

Polasik, M., \& Piotrowska, A. (2014). Transakcyjne wykluczenie finansowe w Polsce w świetle badań empirycznych. Prace Naukowe Uniwersytetu Ekonomicznego we Wrocławiu, (330), 316-325. doi:10.15611/pn.2014.330.34

Rooij, M. van, Lusardi, A., \& Alessie, R. (2011). Financial literacy and stock market participation. Journal of Financial Economics, 101(2), 449-472. doi:10.1016/j.jfineco.2011.03.006

Świecka, B. (2014). Współczesne problemy finansów osobistych. Warszawa: CeDeWu.

Świecka, B. (2018). Kompetencje finansowe i edukacja finansowa. Ujęcie teoretyczne i praktyczne. Rozprawy Ubezpieczeniowe. Konsument na Rynku Ustug Finansowych, 27(1), 3-17. Pobrane z: https:// rf.gov.pl/ru/wp-content/uploads/2018/04/JoIN27_01.pdf

Waliszewski, K. (2010). Doradztwo finansowe w Polsce. Warszawa: CeDeWu. 